\title{
HEMOTOXIC AND GENOTOXIC EFFECTS OF LEAD ACETATE AND CHLORPYRIFOSE ON FRESHWATER CAT FISH (Calarias gariepinus)
}

\author{
Shireen S. Abd El-satar ${ }^{1}$, Nasr E. Nasr² ${ }^{*}$, Khaled A. Khailo², Hossam E. Sayour ${ }^{3}$ \\ ${ }^{1}$ Biochemistry Department, Animal Health Research Institute, Kafrelsheikh, Egypt, ${ }^{2}$ Biochemistry \\ Department, Faculty of Veterinary Medicine, Kafrelsheikh University, Egypt, ${ }^{3}$ Biomedical Chem- \\ istry Unit, Department of chemistry, Animal Health Research Institute, Dokki, Giza, Egypt
}

*Corresponding author, E-mail: nasr_157@yahoo.com

\begin{abstract}
This study was conducted to evaluate hemotoxicity and genotoxicity induced by lead acetate and chlorpyrifos in catfish (Clarias gariepinus) as a model for checking genotoxic pollutants in aquatic surroundings. Lead acetate was added by a dose of 24.4 $\mathrm{mg} / \mathrm{L}(20 \%$ of the LC50) daily, chlorpyrifos was added by a dose of $1.65 \mathrm{mg} / \mathrm{L}(1 / 10 \mathrm{LC} 50)$ daily. Fish were kept in standard condition in which water temperature $\left(25^{\circ} \mathrm{C} \pm 2\right)$; $\mathrm{pH}$ $(7.6 \pm 0.4)$ and dissolved oxygen $(5.4 \pm 0.4 \mathrm{mg} / \mathrm{L})$. Blood and liver were sampled after 4 weeks. The result revealed a significant reduction of $\mathrm{RBCs}$ count, $\mathrm{Hb}$, hematocrit in fish exposed to lead and chlorpyrifos. Furthermore, MDA level and catalase activity showed significant increase and decrease, respectively in groups exposed to lead acetate and chlorpyrifos in comparison with the control fish. Toxic effect of lead acetate and chlorpyrifos confirmed by histopathological changes in liver sections which showed marked hepatic vacuolation and parenchymal hemorrhage. DNA damage detected by comet assay also revealed a significance increase in tail length, tail DNA\% and tail moment at sublethal concentration of lead acetate and chlorpyrifos. This study concluded that lead acetate and chlorpyrifos have hemotoxic and genotoxic effect probably through, at least in part, induction of reactive oxygen species and chlorpyrifos has more hemotoxic and genotoxic effect than lead acetate.
\end{abstract}

Key words: catfish; lead acetate; chlorpyrifos; DNA damage

\section{Introduction}

Pollution of the aquatic surroundings is a serious and growing problem, caused by increasing variety and quantity of industrial, agricultural and business chemicals (1-3). Many water pollutants are capable of inducing oxidative stress on fish (4) which consequently led to cellular and tissues damage in fish (5). Heavy metals and pesticides are poisonous to animals just as individuals (6). Heavy metals are considered as the most important pollutants, because of their notable impacts on the aquatic system equilibrium, bioaccumulation in life forms, long term persistence and ability to aggregate in sediments and water (7). Heavy metals, like mercury, cadmium, copper, lead and zinc are the most vital poisons which influence aquatic environment and fish. They are extremely unsafe for the health of fish. These metals can ef- 
fectively affect the vital operations and reproduction of fish; weaken the immune system, and lead to pathological changes (8)

Lead $(\mathrm{Pb})$ is a prevalent, cumulative and insidious environmental waste product that induces a broad range of physiological, biochemical and behavioral dysfunctions (9-11). With the increasing prevalence of lead pollution in the aquatic surroundings, the potential danger of lead to aquatic animals must be evaluated (12). Studies have demonstrated that lead can induce neurological, gastrointestinal, reproductive, circulatory, immunological, histopathological and histochemical effects in the animals and human $(13,14)$. One of the best known impacts of lead is its interference with synthesis of heme (15). High $\mathrm{Pb}$ concentration in soft tissues inactivate alpha-amino levulinic acid dehydratase (ALAD) enzyme which associated with rise of alpha -aminolevulinic acid (ALA) level (16). Increase of ALA level leads to production of reactive oxygen species (17)

Pesticides are used to control pests, insects, aquatic weeds, plant diseases, and Aquatic snails which transfer schistosomiasis. Pesticides have been observed to be very harmful not only to fish but also to the other organisms. (18). Widespread of pesticides and their improper use cause changes in the aquatic medium. Observing of different effects is wanted for good pesticides control (19). Two main types of pesticides; organophosphates and organochlorines, cause serious harmful impact on the aquatic system and their residues present in water are toxic to aquatic organisms $(20,21)$. One such organophosphate, is chlorpyrifos (CPF) [O, O-diethyl-O-(3,5,6 -trichloro-2pyridyl) phosphorothionate] which is broadly utilized for the management of domestic and agricultural pests. CPF utilized additionally for over 10 years to control foliar insects (arthropoda) that influence farming yields, and subterranean termites (22). Oxidative stress which induced by pesticide has been a focal point of toxicological research for the last decade as a potential mechanism of toxicity $(23,24)$. Toxicity of reactive oxygen species counteracted by antioxidant enzymes such as catalase (CAT), su- peroxide dismutase (SOD), and glutathione reductase (GR) (25). Antioxidants protect the cells and tissues from oxidative damage under normal conditions (26). The antioxidants in fish could be considered as biomarkers of exposure to aquatic contaminants (27). Exposure to pollutants causes several biochemical and physiological responses which may be adaptive or lead to toxicity. Thus, it is important that pollutant effects be detected and interpreted in biochemical terms, to show mechanisms of pollutant action, and possible ways to prevent there bad effects (28).

African catfish (Clarias gariepinus) is very important fish because of its high growth rate, high consumer acceptability and high resistance to bad water quality and low oxygen (29). It is omnivorous feeder and a general scavenger with a marked tendency to feed on benthic organisms and this make it in continuous exposure to different pollutants which concentrated in the sediments. Biomagnification of pollutants throuth eating fish which already accumulate chemicals make this fish accumulate pollutants in greater amounts than other herbivorous fish (30). Catfish considered as an excellent model for toxicological studies and has been used in fundamental research (31, 32). Since fish are important as proteins and lipids sources for humans and domestic animals, so health of them is very important for human beings (18). Therefore, this study was conducted to indicate the hemotoxic and genotoxic effect of both chlorpyrifose and lead acetate on African catfish

\section{Materials and methods}

\section{Chemicals}

Lead acetate trihydrate (Mol.Wt. 379.33 g/mol, product No. 316512, purity 95\%)and other chemicals used in this study were purchased from (Sigma-Aldrich), chlorpyrifos was obtained as a commercial product (Pyrifos EL NASR 48\% EC) from (El Nasr Pharmaceutical Company, Cairo-Egypt).

\section{Experimental fish}

Catfish (Clarias gariepinus) of both sexes, average weight 150 were purchased from fish 
farm in Kafrelsheikh, Egypt. Fish was transported in large plastic water containers and maintained in the glass aquaria in the laboratory of faculty of veterinary medicine, Kafrelsheikh University. Fish left without any treatment for two week for acclimation before starting the experiment. Fish were kept in standard condition during the period of acclimation and the experiment in which water temperature is $25^{\circ} \mathrm{C} \pm 2$, $\mathrm{pH}$ is $7.6 \pm 0.4$ and dissolved oxygen $(5.4 \pm 0.4$ $\mathrm{mg} / \mathrm{L})$. Water was supplied with oxygen by air pump, fish kept in 12/12hour light and dark, and were fed on commercial high protein diet (30 $\%$ ) at ratio of $3 \%$ of body weight/day. The water was changed every 2 days to prevent the accumulation of fecal matter and to maintain the pollutants concentration.

\section{Experimental design and treatment}

A total of 120 fresh water catfish were divided into three groups, each group has two replicates (20 fish replicate), kept in $(100 \times 50 \times 30$ $\mathrm{cm})$ glass aquaria contain 100L tap water (dechlorinated); the first group (G1) was considered as control group, the second group (G2) was exposed to lead acetate by a dose of 24.4 $\mathrm{mg} / \mathrm{L}\left(20 \%\right.$ of the $\left.\mathrm{LC}_{50}\right)$ (33) and the third group(G3) was exposed to chlorpyrifos by a dose of $1.65 \mathrm{mg} / \mathrm{L}\left(1 / 10 \mathrm{LC}_{50}\right)$ (34), for 4 weeks, the water was changed every 2 days to avoid the accumulation of fecal matter and to maintain the toxicant concentration.

\section{Blood and tissue samples}

By the end of the experimental period at $4^{\text {th }}$ week, whole blood was collected from caudal blood vessels in clean and dry Eppendorf tubes containing EDTA as anticoagulant, other blood samples were collected without anticoagulant and left at room temperature to coagulate then centrifuged at $3000 \mathrm{rpm}$ for $15 \mathrm{~min}$ and clear sera were separated and kept in $-20{ }^{\circ} \mathrm{C}$ until biochemical analysis. Fish were then killed by spinal rupture; the liver was rapidly excised and divided into three parts: the first part was kept in sterile Eppendorf tube, was immediately immersed in liquid nitrogen and then kept in -20 ${ }^{\circ} \mathrm{C}$ for anti-oxidant determination, the second part about (1g) was kept in PBS in sterile plastic tubes then was stored in $-20{ }^{\circ} \mathrm{C}$ for comet assay analysis and the third part was stored in $10 \%$ formalin for histopathological analysis.

\section{Hematological analysis}

Total red blood cell (RBCs $10^{6} / \mu 1$ ) counts were determined by the Natt \& Herrick (35) method $(\mathrm{NH})$ using a Newbauer hemocytometer. The microhematocrit (PCV\%) was estimated by the method of Hesser (36). Hemoglobin $(\mathrm{Hb} \mathrm{g} / \mathrm{dl})$ values were assessed calorimetrically according to method of Wintrobe and Greer (37) by determining the formation of cyanomethemoglobin.

\section{Biochemical analysis}

Malondialdehyde was spectrophotometrically measured in serum based on (38) at wave length of $534 \mathrm{~nm}$, catalase activity was determined in liver homogenates, briefly obtained as follow (homogenize $1 \mathrm{gm}$. of liver tissue in 5 $\mathrm{ml}$ of cold phosphate buffer saline $\mathrm{PH}: 7.4$,centrifuge at $4,000 \mathrm{rpm} / 15$ minute at $4{ }^{\circ} \mathrm{C}$, then used supernatant for assay) according to Aebi (39).

\section{Histopathological analysis}

Fixed liver samples were dehydrated in ascending grades of ethanol, then embedded in paraffin wax, cut into sections of $5 \mu \mathrm{m}$ thickness. Sections were stained using Mayer's hematoxylin and eosin (H\&E) stains according to the method described by Bancroft (40) and were examined under a light microscope. Hepatic histological changes photographed by computer system with a digital camera (Nikon digital camera, Japan).

\section{DNA damage detection}

Comet assay (single cell gel electrophoresis, SCGE) was used to detect any prospective damage for DNA after treatments. DNA strand breaks and alkali labile sites detected by measuring the migration of damaged DNA from immobilized nuclear DNA. The comet assay was performed according to the protocol described by Singh et al., (41) and the calculations were done as previously described (42). 


\section{Statistical analysis}

Data were analyzed by one way (ANOVA), followed by Bonferroni's Multiple Comparison Test to compare the significant differences between different groups. All the data were expressed as mean $\pm \mathrm{SE}$. A value of $\mathrm{P}<0.05$ was considered to be significant.

\section{Results}

\section{Hematological parameters}

The hematological parameters are listed in Table (1). Exposure to lead acetate and chlorpyrifos led to a significant reduction in RBCs count as compared to the control fish. Furthermore, lead acetate and chlorpyrifos exposed group illustrated a significant decrease in $\mathrm{Hb}$ concentration (in comparison with the control group. Also, there was a significant reduction in PCV\% in group exposed to lead acetate and chlorpyrifos when compared with the control group.

\section{Effect of lead acetate and chlorpyrifos on} MDA level and catalase activity

Exposure to lead acetate and chlorpyrifos led to a significant increase in serum MDA level and a significant decrease in hepatic catalase activity as compared with the control fish a (Fig. 1). Furthermore, chlorpyrifos led to a higher increased MDA level than lead acetate.

Effect of lead acetate and chlorpyrifos on DNA (comet assay)

DNA damage in liver of lead acetate, chlorpyrifos-intoxicated fish were detected by comet assay. The results of comet assay were shown in Fig. (2) and Table (2). Fish exposed to lead acetate showed asignificant $(\mathrm{P}<0.05)$ increase in DNA damage as revealed by increase in tail length, tail DNA\% and tail moment. Fish exposed to chlorpyrifos showed a significant $(\mathrm{P}<0.05)$ increase DNA damage with higher damage in chlorpyrifos than lead acetate groups as compared to the control group (G1).

\section{Histopathological changes}

Normal fish (Fig. 3A) showed normal hepatocytes separated with blood sinusoids, while liver of lead acetate -intoxicated fish (Fig. 3B) showed hepatic vacuolation, parenchymal haemorrahge and focal leukocytic infiltration. Furthermore, liver of chlorpyrifos - intoxicated fish (Fig.3C) showed hepatic vacuolation and hepatic necrosis.

Table 1: Effect of lead and chlorpyrifos on hematological parameters in cat fish

\begin{tabular}{|l|c|c|c|}
\hline Groups & RBCs $\left(10^{6} / \mu \mathrm{l}\right)$ & PCV\% & $\mathrm{Hb}(\mathrm{g} / \mathrm{dl})$ \\
\hline Control & $3.90 \pm 0.06^{\mathrm{a}}$ & $39.06 \pm 0.6^{\mathrm{a}}$ & $9.26 \pm 0.07^{\mathrm{a}}$ \\
\hline Lead acetate & $3.10 \pm 0.06^{\mathrm{b}}$ & $31.07 \pm 0.61^{\mathrm{b}}$ & $7.76 \pm 0.08^{\mathrm{b}}$ \\
\hline Chlorpyrifos & $2.91 \pm 0.06^{\mathrm{c}}$ & $29.10 \pm 0.07^{\mathrm{c}}$ & $7.27 \pm 0.05^{\mathrm{b}}$ \\
\hline
\end{tabular}

Mean \pm SE ( $n=5 /$ group) ${ }^{\text {a,b }}$ Means in the same raw with different superscript are significantly different $(\mathrm{P}<0.05)$

Table 2: Comet assay parameters obtained by image analysis in all groups

\begin{tabular}{lccccc}
\hline Group & Tailed \% & Untailed \% & Tails length $(\mu \mathrm{m})$ & Tail DNA\% & Tail moment \\
\hline Normal & 2 & 98 & $1.53 \pm 0.16^{\mathrm{c}}$ & 1.64 & 2.51 \\
\hline Lead acetate & 19 & 81 & $6.13 \pm 0.49^{\mathrm{b}}$ & 5.48 & 33.59 \\
\hline Chlorpyrifos & 29 & 71 & $9.34 \pm 0.70^{\mathrm{a}}$ & 8.02 & 74.91 \\
\hline
\end{tabular}

Different superscript letters in the same column of tail length showed significance difference at $\mathrm{P}<0.05$ 

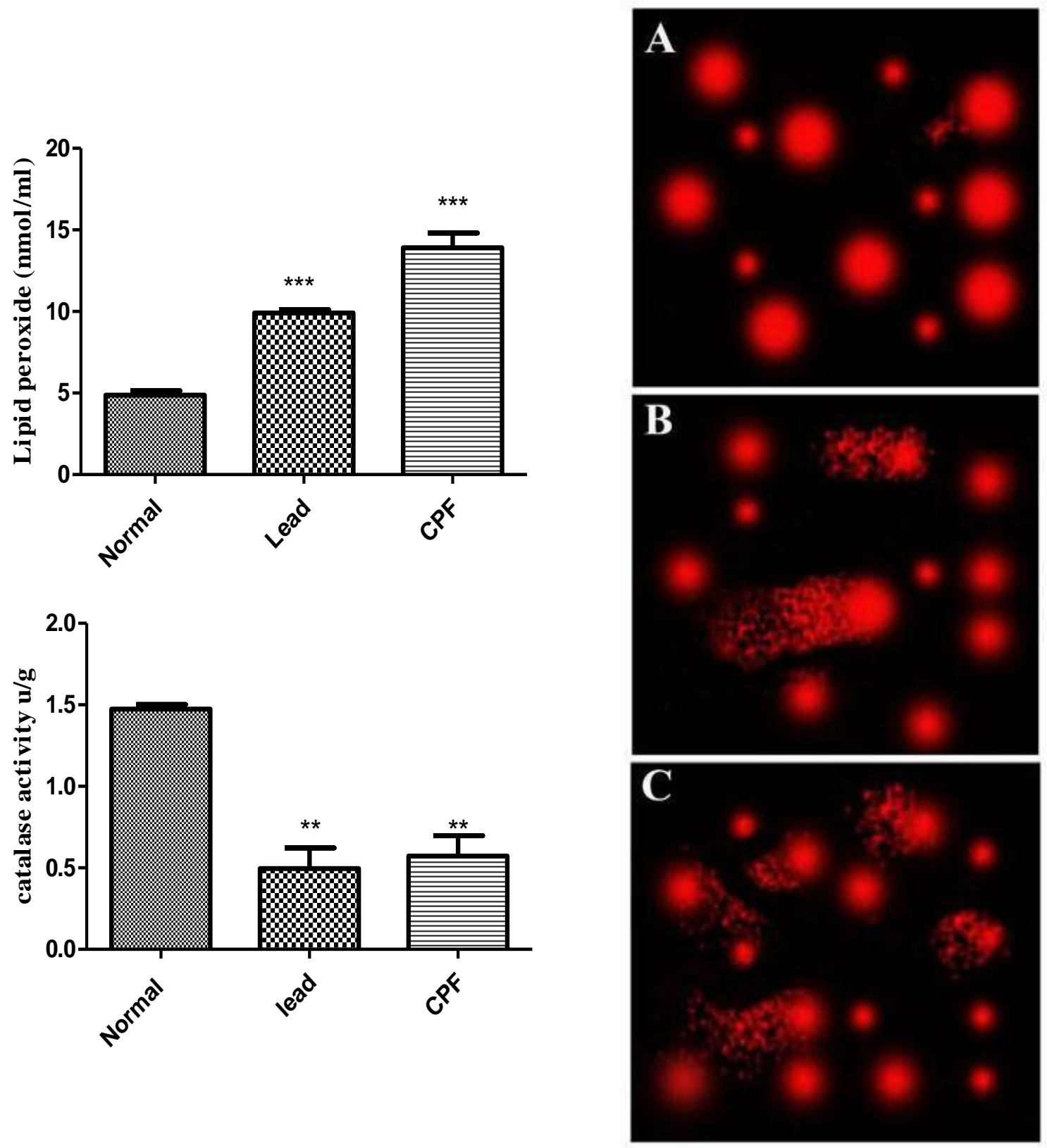

Figure 1: Showing effect of lead acetate and Chlorpyrifos on MDA and catalase activity. Data expressed Mean \pm SE. ( $\mathrm{n}=10$ /group). ${ }^{* P}$ $<0.05$ versus control group

Figure 2: Showing DNA damage (comet assay) in normal fish (A), lead acetate -intoxicated fish (B) and Chlorpyrifos - intoxicated fish $(\mathrm{C})$ 

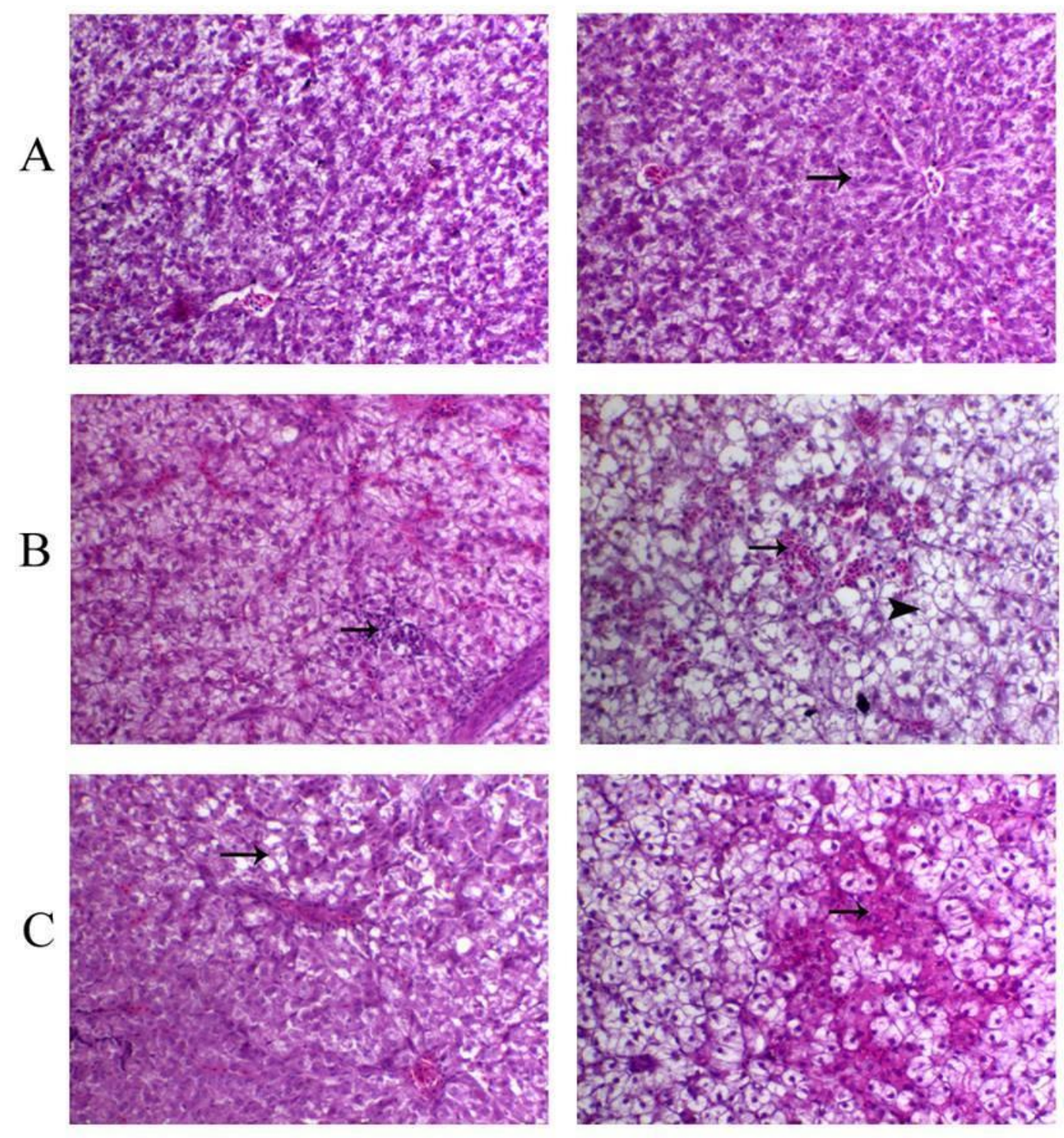

Figure 3: Showing Hematoxylin and eosin (H\&E) stains of liver normal fish (A), lead acetate -intoxicated fish (B) and Chlorpyrifos - intoxicated fish (C)

\section{Discussion}

Because of over population and unintended civilization, many aquatic ecosystems are facing complicate problems of contamination (43). A few contaminates, for example detergents, household waste pesticides, insecticides, bacteria, parasites, metals, salts, acids, and other chemicals have been found in many aquatic surroundings (44). African catfish (Clarias gariepinus) is an excellent model for aquaculture, fundamental research, and environmental contamination studies $(45,46)$, So the present study try to illustrate, hemotoxicity and genotoxicity of lead and chlorpyrifos as pollutant on the Clarias gariepinus fish.

The result of present study revealed a significant decrease of RBCs count, Hb concentration and PCV values in lead acetate -intoxicated fish comparison with control fish. This was in harmony with (33) who reported that sub-chronic exposure of $C$. gariepinus to lead decreased RBCs count. Changes in $\mathrm{Hb}$ concentration and PCV values, were also compatible with 
Adeyemo (47), who reported significant decreases in $\mathrm{Hb}$, RBCs count and PCV values in C. gariepinus exposed to lead nitrate. Lead causes damage of hemopoietic organs, structural damage of $\mathrm{RBC}$ membranes resulting in hemolysis, impairment in hemoglobin synthesis, stress-related release of RBCs from the spleen and hypoxia (48). Lead causes early mortality of mature red blood cells and inhibition of hemoglobin synthesis through inactivation of RBC alpha-amino levulinic acid dehydratase (17). Also, our results revealed that RBCs count, hemoglobin concentration and hematocrit a significantly less in CPF -intoxicated fish in comparison with the control group. This result was compatible with (34) who reported that exposure of freshwater fish Clarias batrachus to chlorpyrifos led to significant decrease in $\mathrm{RBCs}$ and $\mathrm{Hb}$ indicating a condition of erythropenia and hemolysis. This may be attributed to inhibition of erythropoiesis, hemoformation, osmoregulatory dysfunction or due to increased rate of $\mathrm{RBC}_{S}$ destruction in hematopoietic organ by chlorpyrifos (49). Indeed, chlorpyrifos more toxic than lead acetate.

Contaminants can possibly initiate oxidative stress in fish through creation of free radicals and reactive oxygen species (ROS) which lead to an imbalance between intracellular ROS levels and antioxidant defense $(50,51)$. ROS cause damage to proteins, lipids, carbohydrates and nucleic acids (52). This damage may alter cell functions, eventually leading to cell death (53). Our results showed that serum MDA was significantly increased and catalase activity was significantly decreased in fish exposed to lead as compared to the control fish. Similarly, other studies also reported that toxic action caused by lead might be due to its ability to produce ROS which cause oxidative damage in several tissues by increasing lipid peroxidation through Fenton reaction $(54,55)$. We also found a similar change following addition of CPF. Our study revealed that serum MDA was significantly increased and catalase activity was significantly decreased in tissue of CPF-exposed fish. Similar results obtained by Kaur and Jindal (56) who reported that CPF was very toxic to Ctenopharyngodon idellus even at very low concentration. Its administration increases MDA level and affected adversely the antioxidative defense system in different organs of the fish. This study indicated chlorpyrifos more toxic than lead acetate.

Histopathological examination of liver tissue is important marker for exposure to environmental stressors or pollutants, as the liver is important organ of detoxification (57). This study revealed that liver tissue in fish exposed to lead acetate showed hepatic vacuolation, parenchymal haemorrahge and focal leukocytic infiltration, which agreed with Rubio, et al., (58) who reported that lead cause inhibition of mono amino oxidase and acetylcholine esterase, to cause pathological changes in tissue and organs. Additionally, CPF also resulted in vacuolation and hepatic necrosis in hepatic tissue of cat fish, and this was in consistent with Deb and Das (59) who reported that common carp exposed to CPF revealed different degree of hydropic degeneration, vacuolization, pyknotic nuclei, and fatty infiltration in their liver tissue.. Although every metal have distinctive mechanism of toxicity however there are some common mechanism such as mimicry, adduct formation with DNA or protein and oxidative damage. Generation of ROS is caused by heavy metals in their ionic forms leading to oxidative changes in DNA, causing aberrant gene expression and carcinogenesis (60). The present study revealed induction of DNA damage by lead and CPF. In support, other studies also reported exposure to lead cause genotoxic effects, such as chromosome aberration, mutation, DNA breakage and DNA synthesis inhibition $(61,62)$. This result may due to lead can mimic the essential elements such as magnesium, iron, calcium and zinc, increased the production of inaccurate nucleotides in which it implicated as a co- carcinogen and effect on DNA repairing mechanisms (63). Similarly, Yin, et al., (64) reported that chlorpyrifos caused genotoxicity in RBCs and liver cells of Chinese toad (Bufo gargarizans) when the tadpoles were exposed to the sub lethal dose of chlorpyrifos. Indeed DNA damage was higher in chlorpyrifos than lead acetate. 


\section{Conclusion}

This study illustrated that lead acetate and chlorpyrifos have hemotoxicity through decrease RBCs count, $\mathrm{Hb}$ concentration, and hematocrit, generate ROS and has genotoxicity through induction of DNA damage in cat fish after exposure to sub-lethal concentrations. Moreover chlorpyrifos is more toxic than Lead acetate

\section{Conflict of interest}

The authors declare that they have no conflict of interest.

\section{References}

1. McGlashan D, Hughes J. Genetic evidence for historical continuity between populations of the Australian freshwater fish Craterocephalus stercusmuscarum (Atherinidae) east and west of the Great Dividing Range, Journal of Fish Biology 2001; 59: 55-67.

2. Ali F K, El-Shafai S A, Samhan F A, Khalil W K. Effect of water pollution on expression of immune response genes of Solea aegyptiaca in Lake Qarun, African Journal of Biotechnology 2008; 7(10).

3. Mahfouz M, Hegazi M, El-Magd M, Kasem E. Metabolic and molecular responses in Nile tilapia, Oreochromis niloticus during short and prolonged hypoxia, Marine and Freshwater Behaviour and Physiology 2015; 48(5): 319-40.

4. Ayadi I, Monteiro S M, Regaya I, Coimbra A, Fernandes F, Oliveira M M, Peixoto F, Mnif W. Biochemical and histological changes in the liver and gills of Nile tilapia Oreochromis niloticus exposed to Red 195 dye, RSC Advances 2015; 5(106): 87168-78.

5. Pandey S, Parvez S, Sayeed I, Haque R, BinHafeez B, Raisuddin S. Biomarkers of oxidative stress: a comparative study of river Yamuna fish Wallago attu (B1. \& Schn.), Science of the Total environment 2003; 309(1-3): 105-15.

6. Gilliom R J, Hamilton P A, Pesticides in the nation's streams and ground water, 1992-2001-a summary, 2006.

7. Monroy M, Maceda-Veiga A, de Sostoa A. Metal concentration in water, sediment and four fish species from Lake Titicaca reveals a large-scale environmental concern, Science of the Total environment 2014; 487: 233-44.

8. Authman M M, Zaki M S, Khallaf E A, Abbas $\mathrm{H} \mathrm{H}$. Use of fish as bio-indicator of the effects of heavy metals pollution, Journal of Aquaculture Research \& Development 2015; 6(4): 1-13.

9. Patra R, Swarup D, Dwivedi S. Antioxidant effects of $\alpha$ tocopherol, ascorbic acid and Lmethionine on lead induced oxidative stress to the liver, kidney and brain in rats, Toxicology 2001; 162(2): 81-8.

10. Gurer H, Ercal N. Can antioxidants be beneficial in the treatment of lead poisoning?, Free Radical Biology and Medicine 2000; 29(10): $927-$ 45.

11. El-Magd M A, Kahilo K A, Nasr N E, Kamal T, Shukry M, Saleh A A. A potential mechanism associated with lead-induced testicular toxicity in rats, Andrologia 2016; 49(9): e12750.

12. Dai W, Liu S, Fu L, Du H, Xu Z. Lead (Pb) accumulation, oxidative stress and DNA damage induced by dietary $\mathrm{Pb}$ in tilapia (Oreochromis niloticus), Aquaculture Research 2012; 43(2): 20814.

13. Abdallah G M, El-Sayed E-S M, Abo-Salem O M. Effect of lead toxicity on coenzyme Q levels in rat tissues, Food and Chemical Toxicology 2010; 48(6): 1753-6.

14. Nordberg , Fowler, Nordberg , Friberg. Handbook on the Toxicology of Metals. 3rd Edn. Academic press, Amesterdam., ISBN 2007; -10: 0123694132, pp: 10-24.

15. Makino S, Tsuruta H, Takata T. Relationship between blood lead level and urinary ALA level in workers exposed to very low levels of lead, Industrial health 2000; 38(1): 95-8.

16. Flora S J, Pande M, Mehta A. Beneficial effect of combined administration of some naturally occurring antioxidants (vitamins) and thiol chelators in the treatment of chronic lead intoxication, Chemico-Biological Interactions 2003; 145(3): 267-80.

17. Ademuyiwa O, Ugbaja R, Ojo D, Owoigbe A, Adeokun S. Reversal of aminolevulinic acid dehydratase (ALAD) inhibition and reduction of erythrocyte protoporphyrin levels by vitamin $\mathrm{C}$ in occupational lead exposure in Abeokuta, Nigeria, Environmental Toxicology and Pharmacology 2005; 20(3): 404-11.

18. Sabra F S, Mehana E. Pesticides toxicity in fish with particular reference to insecticides, Asian Journal of Agriculture and Food Sciences (ISSN: 2321-1571) 2015; 3(01).

19. Lari S Z, Khan N A, Gandhi K N, Meshram T S, Thacker N P. Comparison of pesticide residues in surface water and ground water of agriculture intensive areas, Journal of Environmental Health Science and Engineering 2014; 12(1): 11. 
20. Banaee M, Mirvagefei A, Rafei G, Majazi Amiri B. Effect of sub-lethal diazinon concentrations on blood plasma biochemistry, International Journal of Environmental Research 2008; 2(2): 189-8.

21. Wang Y, Qiu Y, Fei Y, Li L, Zhu Z, Zhao J, Yao E, Yao Y. Measurement and preliminary human health risk assessment of representative organochlorines in farmed Mandarin fish, Huan jing ke xue= Huanjing kexue 2011; 32(8): 2385-90.

22. Rao J V, Begum G, Pallela R, Usman P, Rao $\mathrm{R}$ N. Changes in behavior and brain acetylcholinesterase activity in mosquito fish, Gambusia affinis in response to the sub-lethal exposure to chlorpyrifos, International Journal of Environmental Research and public health 2005; 2(3): 478-83.

23. Akhgari M, Abdollahi M, Kebryaeezadeh A, Hosseini R, Sabzevari O. Biochemical evidence for free radicalinduced lipid peroxidation as a mechanism for subchronic toxicity of malathion in blood and liver of rats, Human \& experimental toxicology 2003; 22(4): 205-11.

24. Cicchetti R, Argentin G. The role of oxidative stress in the in vitro induction of micronuclei by pesticides in mouse lung fibroblasts, Mutagenesis 2003; 18(2): 127-32.

25. Orbea A, Ortiz-Zarragoitia M, Solé M, Porte C, Cajaraville M P. Antioxidant enzymes and peroxisome proliferation in relation to contaminant body burdens of PAHs and PCBs in bivalve molluscs, crabs and fish from the Urdaibai and Plentzia estuaries (Bay of Biscay), Aquatic Toxicology 2002; 58(1-2): 75-8.

26. Sharawy Z Z, Thiele R, Abbas E M, ElMagd M A, Hassaan M S, Peter C, Schmidt J, Saborowski R, Goda A M A-S, Slater M J. Antioxidant response, body composition of whiteleg shrimp Litopenaeus vannamei co-cultured with Nile tilapia Oreochromis niloticus in recirculating aquaculture, Aquaculture Environment Interactions 2017; 9: 257-68.

27. Ahmad I, Hamid T, Fatima M, Chand H S, Jain S K, Athar M, Raisuddin S. Induction of hepatic antioxidants in freshwater catfish (Channa punctatus Bloch) is a biomarker of paper mill effluent exposure, Biochimica et Biophysica Acta (BBA)-General Subjects 2000; 1523(1): 37-48.

28. Narra M R, Regatte R R, Kodimyala R. Effects of chlorpyrifos on enzymes as biomarkers of toxicity in Fresh water field crab Barytelphusa guerini, International Journal of Environmental Sciences 2012; 2(4): 2015.
29. Karami A, Christianus A, Ishak Z, Courtenay S, Syed M, Azlina M N, Noorshinah H. Effect of triploidization on juvenile African catfish (Clarias gariepinus), Aquaculture international 2010; 18(5): 851-58.

30. Hassanain M, Abdel-Rahman E H, AboHegab S, Tawfik M, Abbas W T. Induction of cytochrome P450 1A1 as a biomarker of Benzo-apyrene pollution in Egyptian fresh water fish, Pakistan journal of biological sciences: PJBS 2007; 10(8): 1161-9.

31. Mekkawy I A, Mahmoud U M, Osman A G, Sayed A E-D H. Effects of ultraviolet A on the activity of two metabolic enzymes, DNA damage and lipid peroxidation during early developmental stages of the African catfish, Clarias gariepinus (Burchell, 1822), Fish physiology and biochemistry 2010; 36(3): 605-26.

32. Sayed A E-D H, Hamed H S. Induction of apoptosis and DNA damage by 4-nonylphenol in African catfish (Clarias gariepinus) and the antioxidant role of Cydonia oblonga, Ecotoxicology and environmental safety 2017; 139: 97-101.

33. Alkahemal-Balawi H F, Ahmad Z, Al-Akel A S, Al-Misned F, Suliman E-A M, Al-Ghanim K A. Toxicity bioassay of lead acetate and effects of its sub-lethal exposure on growth, haematological parameters and reproduction in Clarias gariepinus, African Journal of Biotechnology 2011; 10(53): 11039-47.

34. Narra M R, Rajender K, Reddy R R, Rao J $\mathrm{V}$, Begum $\mathrm{G}$. The role of vitamin $\mathrm{C}$ as antioxidant in protection of biochemical and haematological stress induced by chlorpyrifos in freshwater fish Clarias batrachus, Chemosphere 2015; 132: 172-8.

35. Natt M P, Herrick C A. A new blood diluent for counting the erythrocytes and leucocytes of the chicken, Poultry Science 1952; 31(4): 735-738.

36. Hesser E F. Methods for routine fish hematology, The Progressive Fish-Culturist 1960; 22(4): 164--71.

37. Nwani C D, Somdare P O, Ogueji E O, Nwani J C, Ukonze J A, Nwadinigwe A O. Genotoxicity assessment and oxidative stress responses in freshwater African catfish Clarias gariepinus exposed to fenthion formulations, Drug and chemical toxicology 2017; 40(3): 273-80.

38. Ohkawa H, Ohishi N, Yagi K. Assay for lipid peroxides in animal tissues by thiobarbituric acid reaction, Analytical biochemistry 1979; 95(2): 351-8.

39. Aebi H, [13] Catalase in vitro, Methods in enzymology, Elsevier1984, pp. 121-6. 
40. Bancroft J D, Cook H C, Manual of histological techniques and their diagnostic application, Churchill Livingstone1994.

41. Singh N P, McCoy M T, Tice R R, Schneider E L. A simple technique for quantitation of low levels of DNA damage in individual cells, Experimental cell research 1988; 175(1): 184-91.

42. Badawy A A, El-Magd M A, AlSadrah S A. Therapeutic Effect of Camel Milk and Its Exosomes on MCF7 Cells In Vitro and In Vivo, Integrative Cancer Therapies 2018; 7(4): 1235--46.

43. El-Adawy M, El-Aziz M A, El-Shazly K, Ali N G, El-Magd M A. Dietary propionic acid enhances antibacterial and immunomodulatory effects of oxytetracycline on Nile tilapia, Oreochromis niloticus, Environmental Science and Pollution Research. DOI:10.1007/s11356-0183206-5 2018.

44. Hayati A, Pratiwi H, Khoiriyah I, Winarni D, Sugiharto, Histopathological assessment of cadmium effect on testicles and kidney of Oreochromis niloticus in different salinity, AIP Conference Proceedings, AIP Publishing, 2017, p. 020014.

45. Osman A G, Mekkawy I A, Verreth J, Wuertz S, Kloas W, Kirschbaum F. Monitoring of DNA breakage in embryonic stages of the African catfish Clarias gariepinus (Burchell, 1822) after exposure to lead nitrate using alkaline comet assay, Environmental Toxicology: An International Journal 2008; 23(6): 679-87.

46. Nguyen L, Janssen C. Embryo-larval toxicity tests with the African catfish (Clarias gariepinus): comparative sensitivity of endpoints, Archives of environmental contamination and toxicology 2002; 42(2): 256-62.

47. Adeyemo O K. Haematological profile of Clarias gariepinus (Burchell, 1822) exposed to lead, Turkish Journal of Fisheries and Aquatic Sciences 2007; 7(2).

48. Shah S L. Hematological parameters in tench Tinca tinca after short term exposure to lead, Journal of Applied Toxicology: An International Journal 2006; 26(3): 223-8.

49. Jenkins F, Smith J, Rajanna B, Shameem U, Umadevi K, Sandhya V, Madhavi R. Effect of sublethal concentrations of endosulfan on hematological and serum biochemical parameters in the carp Cyprinus carpio, Bulletin of Environmental Contamination and Toxicology 2003; 70(5): 0993 7.

50. Toni C, Ferreira D, Kreutz L C, Loro V L, Barcellos L J G. Assessment of oxidative stress and metabolic changes in common carp (Cyprinus carpio) acutely exposed to different concentrations of the fungicide tebuconazole, Chemosphere 2011; 83(4): 579-84.

51. Xing H, Wang X, Sun G, Gao X, Xu S, Wang $X$. Effects of atrazine and chlorpyrifos on activity and transcription of glutathione S-transferase in common carp (Cyprinus carpio L.), Environmental Toxicology and Pharmacology 2012; 33(2): 23344.

52. Abdelhady D, El-Abasy M, Abou-Asa S, Elbialy Z, Shukry M, Hussein A, Saleh A, El-Magd $M$. The ameliorative effect of Aspergillus awamori on aflatoxin B1-induced hepatic damage in rabbits, World Mycotoxin Journal 2017; 10(4): 363-73.

53. Sharbidre A A, Metkari V, Patode P. Effect of methyl parathion and chlorpyrifos on certain biomarkers in various tissues of guppy fish, Poecilia reticulata, Pesticide Biochemistry and Physiology 2011; 101(2): 132-41.

54. Leonard S S, Vallyathan V, Castranova V, Shi $X$, Generation of reactive oxygen species in the enzymatic reduction of $\mathrm{PbCrO} 4$ and related DNA damage, Oxygen/Nitrogen Radicals: Cell Injury and Disease, Springer2002, pp. 309-15.

55. El-Sokkary G H, Kamel E S, Reiter R J. Prophylactic effect of melatonin in reducing leadinduced neurotoxicity in the rat, Cellular \& molecular biology letters 2003; 8(2): 461-70.

56. Kaur M, Jindal R. Oxidative Stress Response in Liver, Kidney and Gills of Ctenopharyngodon Idellus (Cuvier \& Valenciennes) Exposed To Chlorpyrifos, MOJ Biol Med 2017; 1(4): 00021.

57. Abdelhady D H, El-Magd M A, Elbialy Z I, Saleh A A. Bromuconazole-induced hepatotoxicity is accompanied by upregulation of PXR/CYP3A1 and downregulation of CAR/CYP2B1 gene expression, Toxicol Mech Methods 2017; 27(7): 544-50.

58. Rubio R, Tineo P, Torreblanca A, Del Ramo J, Mayans J D. Histological and electron microscopical observations on the effects of lead on gills and midgut gland of Procambarus clarkii, Toxicological \& Environmental Chemistry 1991; 31(1): 347-52.

59. Deb N, Das S. Chlorpyrifos toxicity in fish: A Review, Curr. World Environ 2013; 8(1): 77-84.

60 . Ballatori N. Transport of toxic metals by molecular mimicry, Environmental health perspectives 2002; 110 (Suppl 5): 689.

61. 61. Danadevi K, Rozati R, Banu B S, Rao P $\mathrm{H}$, Grover P. DNA damage in workers exposed to lead using comet assay, Toxicology 2003; 187(2-3): 183-93. 
62. Celik A, Öğenler O, Çömelekoğlu Ü. The evaluation of micronucleus frequency by acridine orange fluorescent staining in peripheral blood of rats treated with lead acetate, Mutagenesis 2005; 20(6): 411-5.

63. Fracasso M E, Perbellini L, Soldà S, Talamini G, Franceschetti P. Lead induced DNA strand breaks in lymphocytes of exposed workers: role of reactive oxygen species and protein kinase C, Mutation Research/Genetic Toxicology and Environmental Mutagenesis 2002; 515(1): 159-9.

64. Yin X H, Li S N, Zhang L, Zhu G N, Zhuang H S. Evaluation of DNA damage in Chinese toad (Bufo bufo gargarizans) after in vivo exposure to sublethal concentrations of four herbicides using the comet assay, Ecotoxicology 2008; 17(4): 280-6. 